\title{
PEMBERIAN BANTUAN HUKUM PADA PENGADILAN AGAMA
}

\author{
Oleh : Yasin
}

\begin{abstract}
Abstrak
Undang-undang tentang bantuan hukum sebagaimana yang dikehendaki oleh pasal 38 Undangundang Nomor 14 tahun 1970 belum lahir, oleh karenanya peraturan perundangundangan mengenai ban-tuan hukum sebagian masih meng-gunakan peraturan perundangundangan zaman pemerintahan kolonial Belanda dan beberapa yurispundensi Mahkamah Agung serta beberapa surat Edaran Mahkamah Agung dan menteri kehakiman.

Untuk menjaga tertibnya beracara di Pengadilan Agama serta terlaksananya pengawasan terhadap Penasehat Hukum demi terwujud Penasehat Hukum yang baik dan tertib serta demi terwujudnya wibawa Pengadilan Agama maka aparat Pengadilan Agama khosusnya para hakim Pengadilan Agama perlu memahami peraturan perundangundangan yang menyangkut bantuan hukum.
\end{abstract}

Kata kunci : Bantuan Hukum, Pengadilan Agama

\section{A. Pendahuluan}

Legal aid (Inggris) atau rechtshulp (Belandayistilah baku dalam bahasa Indonesianya "Bantuan hukum" (ps 35 UU No. 14/170 Jo. ps. 35 UU No. 8/181). Pemberian bantuan hukum telah dimulai sejak zarnan Romawi, Walaupun pada saat itu motivasinya hanya untuk mendapatkan pengaruh dalam masyarakat. ${ }^{1}$

Menurut Cappellitti dan Gordley dalam prakteknya bantuan hukum mempunyai dua sistem. Pertama yuridis individual di mana bantuan hukum bertujuan untuk melindungi kepentingan individu. Kedua bantuan hukum model kesejahteraan denga tujuan untuk menegakkan hakhak dan kesej ahteraan. ${ }^{2}$

\footnotetext{
${ }^{1}$ Adnan Buyung Nasution, SH., Bantuan Hukum Indonesia, (Jakarta: LP3ES, 1981), h. 3.

2 Dr. Soerjono Sukanto., Bantuan Hukum Suatu Tinjauan Sosio Yuridis, (Jakarta: Ghalia Indonesia, 1983),
} h. $11-12$. 
Pendapat kedua pakar tersebut mempunyai kesamaan dengan klasifikasi bantuan hukum menurut Hartono Marjono. la berpendapat ahwa bantuan hukum mempunyai dua system, pertama bantuan hokum objektif dan kedua bantuan hukum subjektif dan keduasistem, bantuan hukum objektif. Menurut Marjono dalam prakteknya sistem pertama cenderung negatif karena tujuan akhimya memaksakan kernenangan pihak yang diberikan bantuan dengan menghalalkan segala cara. Sedangkan sistem kedua cenderung positif karena tujuan utamanya mencari keadilan dan kebenaran. ${ }^{3}$

Di Indonesia, menurut Adnan Buyung Nasution, bantuan hukum berfungsi sebagai :

1. Pelayanan bantuan hukum kepada masyarakat yang membutuhkan.

2. Mendidik masyarakatuntuk menumbuhkan dan membina kesadaran akan hak-hak sebagai subjek hukum.

3. Turut serta mengadakan pembaharuan hukum disegala bidang. ${ }^{4}$

Setiap orang yang berperkara dalam proses pemeriksaan perkara di Pengadilan, menurut Subekti, adalah agar :

One.Perkara cepat dapat diselesaikan

Two.Biaya lebih ringan.

Three.Membantu perkembangan hokum. ${ }^{5}$

Setiap orang yang berperkara di Pengadilan berhak memperoleh bantuan hukum. Tujuannya untuk membantu melancarkan penyelesaian perkara dengan menjunjung tinggi Pancsila, hukum dan keadilan. (ps. 35, 37 UU No 14/1970).

Dalam pasal 54 UU No. 7/1989 di atur bahwa "hukum acara yang berlaku pada Pengadilan dilingkungan Peradilan Agama adalah hukum secara perdata yang berlaku pada Pengadilan dalam lingkungan Peradilan umum", yaitu HIR dan RBG.

${ }^{3}$ Hartono Marjono, SH., Pemberian Bantuan Hukum di Lingkungan Peradilan Agama, dalam Mimbar Hukum No. 17 tahun V, 1994, h. 74-75.

${ }^{4}$ Adnan Buyung Nasution, SH., op.cit., h. 5-6.

${ }^{5}$ Prof. Dr. Subekti., Hukum Acara Perdata, (Jakarta: BPHN, 1982), h. 31. 
HIR dan RBG tidak mewajibkan para pihak berperkara untuk meminta bantuan hukum kepada penasehat hukum. Apabila ia menghendaki bantuan hukum, dapat meminta bantuan hukum kepada penasehat hukum. Oleh karenanya Hakim wajib memeriksa perkara yang diajukan kepadanya meskipun tampa bantuan hukum dari Penasehat hukum. ${ }^{6}$

Pemberian bantuan hukum didepan Pengadilan akan terkait dengan masalah Penasehat Hukum, pemberian kuasa, dan surat kuasa. Hal ini penting karena menyangkut apakah bantuan hukum yang dilakukan oleh penasehat hukum telah sesuai dengan peraturan perundangundangan yang berlaku sehingga dapat diterima sebagai penasehat hukum atau tidak sesuai sehingga hams ditolak untuk menjadi penasehat hukum.

Dalam pasal 38 UU14/1970 dikatakan, "Pemberian bantuan hukum akan diatur lebih lanjut oleh UU". Sampai saat sekarang UU tersebut belum lahir. Oleh karenanya menyangkut hal penasehat hukum, pemberian kuasa, dan surat kuasa masih berdasarkan peraturan perundang-undangan dizaman pemerintahan Hindia Belanda untuk sebagian dan peraturan perundang-undangan yang lahir setelah Indonesia merdeka.

\section{A. Penasehat Hukum}

Penasehat Hukum adalah mereka yang memberikan bantuan hukum atau nasehat hukum. Penasehat hukum terdiri dari Advocat, Pengacara praktek, Kuasa insidentil, dan Lembaga bantuan Hukum pada Fakultas hukum.

Advocat diatur dalam Reglement op do Rechterlijke organisanite en het beleid der justitie in Indonesia (R.0) Stb. 1847-23. Advocat diangkat dan diber-hentikan, pada zaman pemerintahan Hindia Belanda, oleh Gubernur General, sekarang oleh menteri kehakiman. Syarat akademik untuk diangkat menjadi Advocat hams sarjana hukum, (Surat Menteri Kehakiman No. KKP. 04, 13-300. 15 Desember 1988).

Seorang Advocat berdasarkan SK Menteri Kehakiman telah memperoleh ijin untuk beracara dimuka Pengadilan disemua lingunon peradilan diselunth wilayah Republik Indonesia. Akan tetapi dalam Sk Menteri Kehakiman tersebut telah pula ditentukan Kota tempat domisilinya diwilayah hukum suatu Pengadilan Tinggi dimana terdaftar dan dimana ia mempunyai kantor untuk menjalankan praktek-nya. Oleh karenanya bila seorang Advocat akan

\footnotetext{
${ }^{6}$ Dr. Sudikno Mertokusumo., Hukum AcaraPerdata Indonesia, (Yogyakarta: Liberti, 1982), h. 15-16
} 
beracara dimuka Pengadilan diluar daerah hukum Pengadilan Tinggi dimana ia berdomisili dan terdaftar hams membuat laporan kepada Pengadilan tinggi dimana ia terdaftar bahwa ia akan beracara dimuka Pengadilan diluar Pengadilan Tinggi tersebut, dan tembusannya disampaikan kepada Pengadilan yang dituju dimana ia akan beracara. (Surat TUADA ULDILTUN No. MA/Kumdi1/6066/V1/87).

Pengacara praktek diatur dalam Regeling van Bijstan en Vertogenwoordiging van Partjen in Bergerlijke Zaken Voor Landraden (Zaakwaarneming) Stb. 1927-496. Pengacara praktek adalah seorang sarjana hukum yang telah mendapat izin berpraktek dari Ketua Pengadilan Tinggi. Pengacara praktek memilik tempat kedudukan yang sudah ditentukan dalam surat izin praktek yang dikeluarkan oleh Ketua Pengadilan Tinggi setempat. Oleh karenanya Pengacara praktek terdaftar di kepaniteraan Pengadilan Tinggi tersebut dan di Kepaniteraan Pengadilan Negeri dimana tempat kedudukannya ditentukan.

Wilayah beracara bagi Pengacara praktek hanya dalam daerah hukum Pengadilan Tinggi yang mengeluarkan izin praktek. Karena itu Pengacara praktek tidak dibenarkan untuk beracara diluar daerah hukum Pengadilan Tinggi terse-but, melainkan hanya dapat beracara dimuka Pengadilan-pengadilan dalam daerah hukum Pengadilan Tinggi yang bersangkutan. Bila Pengacara praktek akan beracara diluar wilayah hukum Pengadilan Negeri dimana ia terdaftar atau akan beracara di luar lingkungan peradilan umum yang ada di wilayah Pengadilan Tinggi yang memberikan izin praktek, maka ia harus memberitahukan kepada Pengadilan Negeri dimana ia terdaftar bahkan ia akan beracara dimuka Pengadilan Negeri lainya atau dilingkungan peradilan lainnya atau tembusannya disampaikan kepada Pengadilan dimana ia akan secara. (Surat TUADA ULDILTUN No. MA/ Kumdil/ 0595/1/1988).

Kuasa insidentil adalah kuasa hukum bukan sebagai profesi. Kuasa insidentil dimungkinkan berdasarkan Stb. 1927-496. Pasal 1 ayat (1) stb. 1927-496 dikatakan bahwa, "siapapun berhak memantau atau mewakili §uatu pihak sebagai kuasa dalm perkara perdata". Dalam pasal itu tidak ada persyaratan bagi seorang yang akan memberikan bantuan hukum kepada salah satu pihak yang berperkara di Pengadilan Negeri.

Yang dianut- Mahkamah Agung kuasa insidentil harus mempunyai hubungan keluarga/ suami, dan orang tua/istri (Surat TUADA ULDILTUN No.MA/ Kumdil/ 8810/IX/1987), yang diberi bantuan hukum. Disamping itu kuasa insidentil harus mendapat izin dari Pengadilan 
dimana ia akan beracara. Menurut Hensyah Syahlani kuasa insidentil hams dibatasi izin beracaranya satu kali untuk satu tahun.

Kuasa insidentil dapat dilakukan oleh Pegawai Negeri dan Perkara hukum dengan persyaratan sebagaimana tersebut di atas dan harus ada izin dan atasannya. (Surat Edaran Mahkamah Agung No. 02/1971). Seorang asisten Advocat yang akan beracara menanc.,'ani suatu perkara dengan surat kuasa substitusi hares dianggap sebagai kuasa insidentil dengan permohonan izin kepada Ketua Pengadilan Tinggi dan Pengadilan dimana ia akan berpraktek. (Surat TUADA ULDILTUN No. MA/KUMDIL/6261/X/1988).

Lembaga Bantuan Hukum Fakultas Hukum dalam rangka membimbing Mahasiswanya ber-praktek hukum pada dasarnya dapat dibenarkan untuk membimbing mahasiswanya untuk berpraktek hukum dimuka Pengadilan Negeri dimanan Lembaga Bantuan Hukum Fakultas itu terdaftar.

Apabila diperlukan untuk membimbing berpraktek hukum pada Pengadilan diluar lingkungan Pengadilan Negeri atau di Pengadilan Negeri diluar daerah hukum Pengadilan Negeri dimana Lembaga Bantuan Hukum itu terdaftar yang masih berada dalam daerah hukum Pengadilan Tinggi yang bersangkutan, maka untuk itu diperlukan izin dari Ketua Pengadilan Tinggi yang mengeluarkan izin prakteknya. (Surat TUADA ULDILTUN No. MA/ Kumdi1/0595/I/1988).

\section{B. Pemberian Kuasa}

Pemberi an K uas.a (last geeing) diatur dalam pasal 1792 s/d 1819 KUH Perdata. Pemberian kuasa adalah suatu perjanjian dimana pihak pertama (Pemberi Kuasa) memberikan perintah kepada orang lain (Penerima untuk melakukan suatu urusan. ${ }^{7}$

Dalam pasal 1792 terdapat kata-kata "atas namanya", menurut Vol'mar kata-kata tersebut mengandung dua kemungkinan: Pertama, Penerima kuasa melakukan perbuatan hukum yang diperintahkan kepadanya atas namanya sendiri, oleh karenanya pihak ketiga yang melakukan perbuatan hukum hanya berhubungan dengan penerima kuasa, kuasa tersebut dinamakan kuasa tak langsung. Kedua, penerima kuasa memberitahukan kepada pihak ketiga, dengan siapa ia mengadakan hubungan, nama dari pemberi kuasa sebagai orang yang bersangkutan dengan transaksinya, oleh karenanya penerima kuasa terlepas dari tanggung jawab perbuatan yang dilakukannya dan pihak ketiga langsung berhubungan dengan pemberi

\footnotetext{
${ }^{7}$ H.V.A. Volmar., Pengantar Studi Hukum Perdata, (Jakarta: Rajawali, 1984), h. 420.
} 
kuasa dalam hal perbuatan hukum yang dilakukannya dengan penerima kuasa. Kuasa tersebut dinamamkan Kuasa langsung. ${ }^{8}$

Pemberian kuasa bersumber dari persetujuan/kesepakatan dan undang-undang. Pemberian kuasa yang bersumber dari persetujuan adalah pemberian kuasa dari seseorang kepada orang lain yang menerimanya untuk melakukan sesuatu atas namanya. Sedangkan pemberian kuasa yang bersumber dari undang-undang adalah pemberian kuasa yang telah diatur oleh undang-undang seperti perwalian ps. 206 KUH Perdata, ps. 50 UU No. 1/1974; curator ps. 433, dan kekuasaan orang tua ps. 47 UU No. 1/1974.

Pemberian dan penerimaan kuasa dapat dituangkan dalam akta autentik, tulisan di bawah tangan, sepucuk surat atau dengan lisan. Disamping itu penerimaan kuasa dapat dilakukan secara diam-diam dan disimpulkan dari pelaksanaan kuasa itu oleh penerima kuasa. Ps. 1793 KUH Perdata. Pemberian kuasa dapat dilakukan secara khusus mengenai satu kepentingan atau lebih, atau secara umum meliputi pengurusan segala kepentingan sipemberi kuasa. Ps. 1975-1976 KUH Perdata.

Pemberian kuasa berakhir dengan:

1. Ditariknya kuasa oleh pemberi kuasa.

2. Pemegang kuasa yang mengundurkan diri.

3. Meninggalnya salah satu pihak, pemberi kuasa atau pemegang kuasa.

4. Pailitnya sipemberi kuasa atau si pemegang kuasa.

5. Pengangkatan seorang kuasa yang baru untuk urusan yang sama, maka pemberian kuasa yang pertama secara otomatis berakhir. Ps. 1816 KUH Perdata.

\section{Surat Kuasa}

Dalam ps. 147 RBG. Jo. Ps. Hir, Penasehat hukum untuk beracara dimuka Pengadilan hares mendapat kuasa khusus dari pihak berperkara. Kuasa khusus dapat dilakukan diluar sidang Pengadilan dihadapan ketua Pengadilan/Hakim yang ditunjuk oleh Ketua Pengadilan pada saat mengajukan gugatan secara lisan, selanjutnya dicatat dalam surat gugatan tersebut. Pemberian kuasa secara lisan dapat pula dilakukan dalam sidang persidangan Peng-adilan yang dicatat oleh Panitera pengganti dalam berita acara persidangan. (ps. 147 ayat I RBG).

\footnotetext{
${ }^{8}$ Ibid., h. 422.
} 
Pemberian kuasa secara tertulis dapat dicantumkan sekaligus dalam surat gugatan, atau dibuat tersendiri oleh notaris, Panitera Pengadilan yang mewilayahi domisili pemberi kuasa, Camat, atau dibawah tangan yang dilegalisir dan didaftarkan menurut Stb. 1916-46. (ps 147 ayat (3) RBG.).

Surat kuasa yang dibuat oleh Notaris yang tidak mencakup wilayah hukum dimana pemberi kuasa/penerima kuasa bertempat tinggal adalah tetap sah, karena undang-undang tidak menentukan syarat bahwa surat kuasa harus dibuat oleh Notaris yang wilayah hukumnya meliputi tempat tinggal pemberi kuasa. ${ }^{9}$

Dalam pasal 57 ayat (3) Undang-undang PTUN dikatakan: "Surat kuasa yang dibuat diluar negeri bentuknya hams memenuhi persyaratan di Negara yang bersang-kutan dan diketahui oleh Perwakilan Republik Indonesia di Negara tersebut, serta kemudian diterjemahkan kedalam Bahasa Indonesia oleh penteijemah resmi".

Yang menj ad i pertanyaan apakah pasal tersebut dapat diberlaktikan untuk lembaga peradilan lainnya. Dalam hal ini Mahkamah Agung memberikan fatwa atas pertanyaan Pengadilan Tinggi Ujung Pandang bahwa, bila surat kuasa dibuat diluar Negeri hams dilegalisir oleh KBRI/Konsulat RI agar dapat dipergunakan sebagai surat kuasa diPengadilan di Indonesia. ${ }^{10}$

Surat Kuasa Khusus yang dibuat oleh Panitera cukup Panietra yang mendatangani dan harus dilegalisir oleh Ketua Pengadilan/ Hakim yang ditunjuk untuk itu oleh Ketua. ${ }^{11}$

Surat Kuasa dibawah tangan menurut pasal 147 ayat (3) RBG hams dilegalisir dan didaftar (oleh Panitera?) dan bila dihubungakan dengan pasal 1793 KUHP Perdata cukup ditandatangani oleh Pemberi kuasa.

Menurut Yahya Harahap, Surat Kuasa dibawah tangan harus ditanda tangani oleh Pemberi Kuasa dan Penerima Kuasa disamping itu berdasarka putusan "Mahkamah Agung No. $779 \mathrm{~K} / \mathrm{Pdt} / 1992$ tanpa legalisasi surat kuasa khusus dibawah tangan telah memenuhi syarat forma $1 .{ }^{12}$

${ }^{9}$ Mahkamah Agung RI., Himpunan Tanya lawab, Jakarta, 1987, No. 280. H. 160

10 M.Yahya Harahap, SH., Beberapa Permasalahan Hukum Acara Pada Pengadilan Agama, (Jakarta: AlHikmah, 1993), h. 16. Lihat, MARI, No. 271 tahun 1987, h. 156.

${ }^{11}$ Ibid., h. 10. Lihat, MARL, No. 150 tahun 1985, h. 103

12 Ibid., h. 13. 
Surat Kuasa Khusus harus memenuhi persyaratan formil. HIR dan RBG tidak secara tegas dan rinci mengenai persyaratan formal yang harus dipenuhi dalam surat kuasa khusus. Dalam hal ini Mahkamah Agung telah mengeluarkan surat edaran Nomor: 6 Tahun 1994 bahwa dalam perkara perdata haurs jelas disebutkan para pihak berperkara dan jenis perkara yang disengketakan.

Menyimpang dari surat edaran tersebut adalah putusan Mahkamah Agung No. 453 K/Sip/ 1973, bahwa surat kuasa yang tidak menentukan jenis perkara tertentu dianggap memenuhi surat kuasa khusus bila memberi kuasa hadir sendiri dipersidangan didampingi oleh penerima kuasa. Demikian hal-nya surat kuasa yang tidak menyebutkan identitas Tergugat, berdasar-kan keputusan Mahkamah Agung No. 425 K/Pdt/ 1984, bila ternyata dalam beberapa kali sidang Penggu-gat sendiri secara pribadi didampingi kuasa, harus dianggap Penggugat tidak keberatan didampingi kuasanya dalam segala sesuatu yang berhu-bungan dengan perkara tersebut. $^{13}$

Surat Kuasa Khusus dapat dipergunakan dalam semua tingkat pemeriksaan, bila dalam surat kuasa khusus tersebut ditegaskan bahwa surat kuasa tersebut, berlaku untuk tingkat Pengadilan Pertama, Banding dan Kasasi. ${ }^{14}$ Bahkan berdasarkan putusan Mahkamah Agung No. 202 K/Sip/1953 6 Juli 1955, Surat kuasa yang berisikan "penguasaan menggunakan segala upaya hukum" mencakup pemberian kuasa untuk mengajukan permohonan Banding. ${ }^{15}$ Akan tetapi menurut Yahya Harahap, mengutip putusan Mahkamah Agung No 51 K/Pdt/1991 tangal 25 Januari 1992, surat kuasa yang mencantumkan untuk kasasi dalam surat kuasa khusus untuk tingkat pertama dan banding tidak dibenarkan lagi, dihitung sejak berlakunya UU No. 14 tahun 1985. Unutk Kasasi hares dibuat surat kuasa khusus untuk itu.

\section{Pengawasan Terhadap Penasehat Hukum}

Pengawasan terhadap Penaseh at hukum dilakukan oleh Mahkamah agung dan Pemerinfah. Umumnya pembinaan dan Pengawasan atas penasehat hukum adalah tanggung jawab Pemerintah. Khusus dalam menyelenggarakan tugastugasnya yang menyangkut perdilan,

${ }^{13}$ Ibid., h. 14.

${ }^{14}$ MARI, No. 49 tahun 1987, h. 29.

15 Olden Bidara, SH., Hukum A cara Perdata, (Jakarta: Pradnya Paramita, 1987), h. 16. 
para penasehat hukum berda dibawah pengawasan Mahkamah Agung. (Ps. 36 UU No. 14/1985 Jo Penjelasan pasal tersebut).

Hal yang menyangkut tata cara pengawasan, penindakan dan pembelaan diri penasehat hukum diatur dalam Keputusan Bersama Ketua Mahkamah Agung dan Menteri Kehakiman Republik Indonesia Nomor: K.MA/005/SKB/ VII/1987- Nomor M. 03-PR 180.05 Tahun 1987 tanggal 6 juli 1987.

Pelaksanaan pengawasan sehari-hari atas para Penasehat Hukum dilakukan oleh Ketua Pengadilan Negeri setempat dan selanjutnya secara hirarkis dilakukan oleh Ketua Pengadilan Tinggi, Ketua Mahkamah Agung dan Menteri Kehakiman. Para Ketua Pengadilan dari lain lingkungan peradilan membantu dalam melaksanakan pengawasan yang perlu kepada Ketua Pengadilan Negeri yang daerah hukumnya meliputi tempat kedudukan Penasehat Hukum yang bersangkutan. (ps. 2 ayat (1) dan ayat (4) Surat Keputusan bersama Mahkamah Agung dan Menteri Kehakiman tersebut di atas).

Perbuatan-perbuatan yang akan berakibatkan seorang Penasehat Hukum dapat dikenakan penindakan diatur dalam pasal 3 SKB tersebut, yang pada intinya sama dengan yang diatur dalam pasal ps. 192 ayat (9) Reglement op de Rechterlijke Organisatie on het Beleid der Justitie in Indonesie (RO), yakni pihak-pihak sebagai berikut:

1. Mengabaikan atau menterlantarkan kepentingan kliennya

2. Berbuat atau bertingkah laku yang tidak patut terhadap lawannya atau kuasanya;

4. Berbua, Bertingkah laku, bersikap bertutur kata atau mengeluarkan penyataan yang menunjukkan sikap tidak hormat kepada hukum, undang-undang, kekuasaan umum, Pengadilan dan pejabatnya;

5. Berbuat hal-hal yang bertentangan dengan kewaj ib an atau bertentangan dengan kehonnatan dan martabat pro fesinya;

6. Melakukan pelangaran terhadap oeraturan yang berlaku.

Dalam pengawasannya, Ketua Pengadilan Negeri yang daerah hukumnya meliputi tempat kedudukan Penasehat Hukum yang bersangkutan yang pertama, berwenang menerapkan penindakan teguran lisan atau tertulis, peringatan keras dengan surat, rnemberhentikan sementara dari jabatannya 3 (tiga) sampai 6 (enam) belum secara bertahap. Kedua, disamping mem-berikan hukuman 
tersebut di atas dapat mengusulkan penindakan yang lebih berat yaitu pemberhentian sementara lebih dari enam bulan dan pemberhentian dari jabatannya sebagai Penasehat Hukum.

Wewenang Ketua Pengadilan Tinggi dalam tingkat banding administratif adalah:

1. Pembatalan keputusan administratif Ketua Pengadilan Negeri yang telah mengenakan penindakan pemberhentian sementara dari jabatan Penasehat Hukum selama 3 (tiga) sampai 6 (enam) bulan.

2. Memperbaiki penindakan yang telah dikenakan tersebut (pemberhentian sementara dari jabatan Penasehat Hukum selam 3 sampai 6 bulan), maksudnya memper-baiki mengenai lamanya masa pemberhentian sementara yang dikenakan.

3. Mengusulkan penindakan yang lebih berat dari penindakan yang telah ditetapkan oleh Pengadilan Tinggi.

4. Memberikan putusan penindakan pemberhentian dari jabatan penasehat hukum bagi Pengacara praktek.

Wewenang Ketua Mahkamah Agung dalam pengawasan Penasihat Hukum terbatas pada pembatalan, perbaikan keputusan Ketua Pengadilan Tinggi ditingkat banding administratif mengenai lamanya pemberhentian sementara atau pemberhentian dari jabatan Penasehat Hukum bagi Pengacara praktek.

Disamping itu bila terdapat cukup alasan yang memberatkan baik atas dasar penilaiannya sendiri atau atas dasar persetujuan atas usul-usul yang datang dari Ketua Pengadilan Negeri atau ketua Pengadilan Tinggi, Ketua Mahkamah Agung dapat mengusulkan penindakan yang lebih berat kepada Menteri Kehakiman berupa pemberhentian dari jabatannya sebagai Penasehat Hukum.

Menteri Kehakiman setelah mempertimbangkan sedalam-dalamnya dengan memperhatikan pertimbangan Ketua Mahkamah Agung, pendapat dari organiSasi -proTe-irdarrpembelaan dari penasehat hukum yang bersangkutan dan berkesimpulan bahwa terdapat cukup alasan untuk mengenakan penindakan pemberhentian sementara di atas enam bulan atau pemberhentian dari jabat-annya sebagaia Penasehat Hukum, maka Menteri Kehakiman mengelu-arkan keputusan tentang pemberhentian sementara atas pemberhentian yang bersangkutan sebagai Penasehat Hukum.

Untuk kesempurnaan dan tertibnya administrasi pengawasan maka setiap Pengacara praktek harus mendaftarkan diri izin prakteknya pada Pengadilan Negeri yang telah ditentukan 
dalam surat izin yang dikeluarkan oleh Pengadilan Tinggi dan setiap dua tahun sekali surat izin tersebut harus diperbaharui untuk perpanjangan izin praktek.

Bagi para advokat tidak diperlukan perpanjangan izin praktek karena Keputusan Menteri Kehakiman mengenai pengangkatannya sebagai Advokat berlaku selama tidak diberhentikan sementara atau diberhentikan dari jabatannya sebagai penasehat hukum, akan tetapi setiap dua tahun sekali harus melakukan daftar ulang Advokat. (Surat Mahkamah Agung No. MA/kumdt 205/11/87).

\section{E. Kesimpulan}

Undang-undang tentang bantuan hukum sebagaimana yang dikehendaki oleh pasal 38 Undangundang Nomor 14 tahun 1970 belum lahir, oleh karenanya peraturan perundangundangan mengenai ban-tuan hukum sebagian masih meng-gunakan peraturan perundangundangan zaman pemerintahan kolonial Belanda dan beberapa yurispundensi Mahkamah Agung serta beberapa surat Edaran Mahkamah Agung dan menteri kehakiman.

Untuk menjaga tertibnya beracara di Pengadilan Agama serta terlaksananya pengawasan terhadap Penasehat Hukum demi terwujud Penasehat Hukum yang baik dan tertib serta demi terwujudnya wibawa Pengadilan Agama maka aparat Pengadilan Agama khosusnya para hakim Pengadilan Agama perlu memahami peraturan perundangundangan yang menyangkut bantuan hukum.

\section{DAFTAR KEPUSTAKAAN}

Adnan Buyung Nasution, SH., Bantuan Hukum di Indonesia, LP3ES, Jakarta, 1981.

1st. T. Hamid, Praktek Peradilan Perkara Perdata, Al-Ihsan, Surabaya, 1980.

Hartono Marjono, SH., Penzberian Bantuan Hukum di Lingkungan Peradilan Agama, dalam Mimbar Hukum, No. 17 tahun V,1994.

Hamsyah Syahlani, SH. , Rangkuman in Service Training Hakim Pengadilan Agama, Jakarta, 1993.

Ichtiar Pam-Van Houve, Himpunan Peraturan Perundang-undangan Republik Indonesia Intermasa, Jakarta, 1989.

Mahkamah Agung RI., Himpunan tanya jawab 1985, Jakarta, 1985.

---------, Himpunan tanya jawab 1986, Jakarta, 1986.

--------, Himpunan tanya jawab 1987, Jakarta, 1987. 
---------, Himpunan Surat Edam'? Mahkamah Agung 1951 1978, Jakarta, 1979.

---------, Himpunan Surat Edaran Mahkamah Agung 1979- 9185.

-, Himpunan Surat Edaran Mahkamah Agung 1986- 1988, Jakarta, 1988.

-.--,Kumpulan Surat Edaran Mahkamah Agung RI, Tentang Surat Kuasa dan Penasehat Hukum, Jakarta, 1992.

-..--,Himpunan Peraturan Perundang-undangan Tentang Kekuasaan Kehakiman Mahkamah Agung, Peradilan Umum, Peradilan Militer, Peradilan TUN, dan Organisasi dan Tata Kerja Kepaniteraan/Sekretariat Jendral Mahkamah Agung RI, 1993.

15th. Bidara, SH, HukumAcara Perdata, Pradnya Paramita, Jakarta, 1987.

Tresna, Er. , Komentar HIR, Pradnya Paramita, Jakarta, 1982.

Soeriono Soekanto, Dr, Bantuan Hukum Suatu Tiqjauan Sosio Juridis, Ghal i a Indonesia, Jakarta, 1983.

Subekti, Prof. Dr. , Hukurn .4cafirPerdata, BPHN, Jakarta, 1982.

-------, Pokok-Pokok dari Hukurn Perdata, Intemiasa Jakarta, 1975.

Sudikno Mertokusumo, Dr., Hukum Acara Perdata Indonesia, Liberti, Yogyakarta, 1982.

Supomo, Dr., Hukurn Acara Perdata Pengadilan Negeri, Pradnya Paramita, Jakarta, 1985.

Wirjono Pojodikoro, Dr., Hukurn Acara Perdata di Indonesia, Sumur Bandung, Bandung, 1975.

Yahya Harahap, SH., Beberapa Permasalahan Hukum Acara Pada Peradilan Agama, AlHikmah, Jakarta, 1993.

8th. V. A. Volmar., Pengantar Studi Hukurn Perdata, Rajawali, Jakarta, 1984. 